\title{
Language and the Upward Mobility in Social Classes: A Sociolinguistic Study at Dusun Tutuk-Jerowaru East Lombok
}

\author{
Arka Suwandi; Nuriadi; Muhammad Amin \\ Mataram University, Indonesia
}

http://dx.doi.org/10.18415/ijmmu.v6i2.687

\begin{abstract}
This study is aimed to find out the influence of the upward mobility in social classes on the language style used at Dusun Tutuk community and also identify the factors that influence the upward mobility in social classes on the language style used. Then, analyze the relation between the upward mobility in social classes and the language style used at the community. Population of this study were the people at the village, the sampling technique was purposeful sampling, which allows the writer to sellect samples randomly from the population. This study is descriptive-qualitative design with focusing on the ethnography design. Observation, recording, interview and note taking were the technique of collecting the data. The result of the study showed that there are two language styles used: base alus or refine language and base jamak or non-refine language. Base alus belonged to the nobles and base jamak belonged to the non nobles. However, at Dusun Tutuk, Jerowaru East Lombok, base alus was not only used by the nobles but also by the non nobles when they interacted with both the nobles and the non nobles. These phenomena were influenced by three factors: educational level, religious level and social classes in community. Base alus was not only used by the nobles but also by the non nobles who had high education and who hold important political roles in the society and those included religius figures $(e . i$ $u s t a d z$, hajj). The base jamaq was not only used by the non nobles but also by the nobles who had no power in the society, low income and low education. The study also found that language is a symbol of identity where style was used as one way of showing the identity of the speakers. In the sasak community, appropriate language should be used to appropriate persons, regardless of the status as nobels or non nobbles.
\end{abstract}

Keywords: Language; Upward Mobility; Social Classes; Sasak Community

\section{Background of Study}

Human beings use language as a means to communicate each other and to express their feelings. Halsett (in Stella 1989: 22) defined language as the symbolic code that underlies verbal communication. As the symbolic code, language can be viewed as a dynemic set of sensory symbol of communication and elements used to manipulate them, which symbolically represents something other than itself. All people around the world use language for their communication and interaction. Most of them have a mastery of their own language. Indonesia is a country which is consisted of multiethnic group, races as well as 
language. Every society has their own indegineous language based on their ethnic group called local language (bahasa daerah) beside the national language (bahasa Indonesia).

Local language is the language that is used in a region, ethnic language i.e. Javenese language, Sundanese language and Batak language (Sugiyono, et al, 2008: 119). In Lombok island, bahasa Sasak exists as local language of the indegineous people of Lombok. Base Sasak (Sasak language) is one of the regional or local languages in Indonesia which is spoken primarily by about three million of sasak people (Sasak speakers). Generally, sasak language has been classified into two styles of language; these are base alus (refined language) and base jamak (non-refined language).

Furthermore, Mahyuni (2004) devided Sasak language into two styles; base alus which is used by noble (menak) and base jamak is used by non noble (non-menak). These two groups of people have different style of language uesd. Noble people (menak) identically use base alus (refine language) in expressing politeness, such as 'medahar' (eat), 'nggih' (yes), 'tiang' (I), etc. While the non nobles use a simple form of base jamaq (non-refined language) in expressing politness, such as; 'ape' (what), 'aku' (I), 'mangan' (eat), etc.

In accordance with language and upward mobility in social classes, Mahyuni (2006) has conducted a research on language style and community in Lombok entitled "Speech Styles and Cultural Consciousness in Sasak Community". However, based on the writer's observation there is no previous researcher who has conducted a similar study on language style and upward mobility in social classes at Dusun Tutuk-Jerowaru East lombok. It becomes one of the reasons why the writer chooses Dusun Tutuk as the setting place of the research. Dusun Tutuk is located at Sourth Jerowaru district, East Lombok. This area consists of two different groups of community; noble and non-noble community who speak both refined language and non-refined language which are to be investigated.

Two groups of community use different language style used when they do the interaction. In this case, people at Dusun Tutuk community use refined language when they communicate with the noble people although they do not as noble to show their respect. In the other hand, noble community use nonrefined language when they communicate with the non-noble, but if the non-noble community has high education or high posistion in the community i.e ustadz, hajj then, the noble people use refined language to show their respect too. Interestingly, people at Dususn Tutuk use refined language not because of the social classes as a noble or non-noble but rely on the social position at the society and the educational level. At Dusun Tutuk community, the most dominant position in using refined language is a status as hajj, ustadz, and the position in the community such as kadus and kades also followed up by the educational level.

Basically, a social class refers to a class of people who have certain similarities in the areas of society such as economy, education, job, status, caste etc (Sumarsono, 2000:43). Every aspect of social classes usually has a social character and variety of languages. Social class is a distinction of community members into a level of social status which has the distinction so that the members of each class is relatively the same in term of status and the other class members have the status of higher or lower.

Category of social classesis usually arranged in hierarchy, ranging from the status of low to high. A social class is a stratum of group society who has equal position in the social status. In the society there are people who have the same social position or social status. Those who have the same social position would be in the same social status too. Based on some notion of social classes above, it can be inffered that social class is a classification or differentiation of communities' position into the hierarchy or certain classes within each member of the class based on equality of power, economy, job, education, status and caste.

\section{Research Design}

The method of analyzing data in this study is by using descriptive-qualitative design with focusing on the ethnographic design. Ethnographic design is qualitative procedures for describing, analyzing, and interpreting a culture group's shared patterns of behavior, beliefs, and language that develop over time (Creswell, 2012: 21). 
Based on this method the researcher tries to identify how the language style is used and applied in the Sasak Community at Dususn Tutuk influenced by the upward mobilty in social classes and seek to find the factors that cause the upward mobility of social classes in the community as well. Furthermore, the researcher will analyze the data systematically in the purpose of getting the accurate results. Since the study is conducted at Dusun Tutuk community, the population of this reseach is all of the people who live at Dusun Tutuk coommunity. Dusun Tutuk consists of seven RTs, including RT Tutuk Bat, with a total population of over three thousand people. Dusun Tutuk is settling with arround $90 \%$ non-noble (nonmenak), $8 \%$ noble (menak), and 2\% come from other ethnic. Meanwhile, the educational level of the people at Dusun Tutuk is about 10\% S1, 17\% Senior High School, 18\% Junior High Sschool, 20\% Elentary School and 35\% not gradueted from Elementary School.

To limit this study, the researcher uses purposeful sampling. The researcher chooses six categories of people at the community as the sample by considering their different educational level, age, economic, status and social position in the society. The six categories of people at the community are: rich people, religius figurs ( $u s t a d z$, hajj), prominent figures, people position in the socoiety (kadus, kades) educated people, and ordinary people. In purposeful sampling, the researcher intentionally sellects the individuls and sites who can best help to understand the phenomenon (Creswell, 2012: 206). In deciding the purposeful sampling, the writer has to be sure that the sample must represent the population in which the sample is the characteristic of the population and should be the subject of the entire population.

The source of the data is the communication and interaction of the people at Dusun Tutuk community. There are two types of data source in this study, they are: verbal and non-verbal sources. The verbal source is the data taken from communication of the pepole at Dusun Tutuk. Meanwhile the nonverbal source is the interaction and the references from any resources which is known well about the historical ethnic about Dusun Tutuk and its society such as prominent figure in the society (tokoh or sesepuh masyarakat).

In collecting the data, the researcher uses some techniques such as observation,recording, note taking and interview. Observation was intended to decide Dusun Tutuk community that become the source of the data. The factor that determines the people at Dusun Tutuk community to be analyzed is the frequency of communication and conversation among the people at the community. So, the observation will be focused on the conversation and communication among the people in the community. Recording was intended to get the real data about the upward mobility in social classes and the language style used by the people at the community. In this research, hand phone will be used as the recorder. Note taking will be used during the observation which is intended to support the data recording which will be used for the next step of collecting the data. The researcher will make a note if there is something happen in surrounding during the observation and recording which is related with the study. Interview is a conversation between an investigator and an individual or a group of individuals in order to gather information. The researcher will interview the people who have roles in the society i.e Kadus, Ustadz, and Hajjor people who know well the historical background of Dusun Tutuk community such as the prominent figur of the society (sesepuh atau tokoh masyarakat) to tkae the data for this study.

The method of data analysis in this study is by using ethnography of speaking proposed by Hymes. The ethnography of speaking is the analysis of communication within the wider context of the social and cultural practices and beliefs of the members of a particular culture or speech community (Hymes, 1964). Then, the data collected will be analyzed by the following terms:

\section{Transcription}

The first step is transcribing the data into word, phrase, and sentence. In this case, the researcher will decide to transcribe the data recording. The data transcribtion will be done by listening the selected data and writing out the verbal content of the interaction without any specific symbols.

\section{Identification}

The next step of data analysis is to identify the word, phrase, or sentence that have trancribed. This step is intended to fill the first research question which is to find out the influence of the upward mobility 
in social classes on the language style used at the community. The researcher will identify the word, phrase, or sentence to find out the influences of the upward mobility in social classes on the language style used at Dusun Tutuk Community.

\section{Interpretation}

The last step of data analsis is to interprate the word, phrase, or sentence that are used by people at the community. This step is intended to answer the second and third research question. Once the data that have been identified into the factor that influence the upward mobility in social classes on the language style used at the community, it will be calculated and interprated in order to find out the factors that influence the upward mobility on the language style used at the community. This interpretation also is intended to fill the third research question which is to analyze any relation between the upward mobility and the language style used at the community.

\section{Result and Analysis}

\subsection{Language Style Used at Dusun Tutuk Community}

On the table 1.1, the original form of language style used at Dusun Tutuk community, shown that non menak to non menak used base jamak, but in fact non menak and non menak also may use base alus. The following example taken from the result of data recorded of the research.

Table 1.1 the original form of language style at Dusun Tutuk community The conversation is between non noble and non noble.

\begin{tabular}{|c|c|l|}
\hline No & $\begin{array}{c}\text { Initial } \\
\text { Name }\end{array}$ & \multicolumn{1}{|c|}{ Conversation } \\
\hline 1 & $\mathrm{~S}$ & $\begin{array}{l}\text { Jarin ndk singgitan anuk } \\
\text { niki. } \\
\text { (something is hidden) }\end{array}$ \\
\hline 2 & $\mathrm{M}$ & $\begin{array}{l}\text { nunasan napi nike. } \\
\text { (what is that) }\end{array}$ \\
\hline 3 & $\mathrm{~S}$ & $\begin{array}{l}\text { teres nike. } \\
\text { (the ant) }\end{array}$ \\
\hline 4 & $\mathrm{M}$ & $\begin{array}{l}\text { kan sampun tang tetehan } \\
\text { nike. Masih arak teres nike } \\
\text { (I have trough it. Is there } \\
\text { anything left?) }\end{array}$ \\
\hline
\end{tabular}

The participants on the conversation above indicated to the non noble, but as we can see they mantain their communication with base alus. When M excused S, he used word "nunasan" the alus form of "aneh" which means "please". They rather used base alus (refined language) than base jamak (nonrefined language) although they are indecating to the non nobles. In return S responds with word "nike" the "alus" or polite form of "nikn" which means "this".

However in the daily life communication of community the writer found that sometimes base alus not only used by menak to menak or non menak to menak but it also used by non menak to non menak even menak to non menak based on the factors influenced in maintaining the communicaton in the daily life of community. 
3.2 Factors that Influence the Upward Mobility in Social Classes on the Language Style Used were educational level, religiousity level, and social posisition in the community

\section{Education Level}

The first conversation is between SR (Slamet Riadi, 28 years old male S1 nurse works at Puskesmas Jerowaru, non noble), MI (Muh. Ihsan 36 years old a teacher at MA Darul Aitam Jerowaru male and non noble, now as candidate DPR D Kab. LOTIM) and B (Bawani, 58 years old, male and non noble. The head master of SDI T Al-KAUTSAR Muhajirin). The communication occured at MI's house when SR asking MI's program in political campaign to sosialisation the vision and mision. The communication is taken from conversation III in the data recorded from line 1-6.

\section{Exract 1.7 from the conversation III.}

\section{The conversation is among educated non noble people.}

1. SR: ampure kanda. Napi jari isin kampanyen te lemak?

Excuse me brother. What is contain campaign our tommoro?

(Excuse me brother, what is the contain of our campaign tomorrow?)

2. MI: oohh marak niki dinda, tiang pelungguh sak sampun hadir mangkin niki bagi-bagi tugas ntan gih?

Oohh, like this brother, I you who have come now this share assigment ok? (ohh it likes this brother. We all who have come here right now have assigment each other.. )

3. B:Nggih, sanak. Berembe misal tyang kance sak lainan marak amaq Jon?

4. Yes, son. How if I with the other like Mr. Jon?

(yes, son. How if I with the other like Mr. Jon?)

5. MI: tetep nike jak bpk, program sak pelunguh sampun jalanan kance amaq Jon niki teros wah lanjutan.

Still like that sir. Program that you have run with Mr. Jon this keep have continued. (still like that sir. The program that you have run it wit Mr. Jon still keep going)

Generally, the conversation above indecates that well educated people used base alus even thought they are not belong to non noble. O the line 1 SR address MI with "ampure" which is mean "Sorry". The word ampure indicated to polite form or base alus from word "maaf" in the line 2. In return, B address MI with word 'nggih' polite form or base alus of "yes". The non noble usually use "aok". In the line 4 MI address B with word "nike" the alus form of "nu" which is mean "that". The participants in the conversation above are rather to use base alus or refined language than base jamaq or non refined language to show their respect and honers each other althought they are not noble or non menak because they are educated people.

From the conversation above, the writer notice that the educational level has influenced on the language style used in the daily conversation of the community. In this case the communication among non noble which is well educated will use base alus in their daily conversation rather than base jamak. The way how they show their respect to each other and shown their identity through language used. 


\section{Relegiosity level (Ustadz)}

After collecting the data, the writer found that the religiosity level of the community also influenced the language style used in the daily life of community. The following sample shown the language style used in the religion setting by relegious figurs which is totally arranged by base alus. The sample is between BR (Bapak Rohini 60 years old male non noble) and UN (Ustadz Nur 35 years old)male non noble). The conversation occured when BR talking to UN to please UN leading acare ngurunsan "Ngurisan Cerimony" at one of the neighbor house (Amak Ali). The sample is taken from conversation $\mathrm{V}$ on the data line 1-6.

\section{Exract 1.4 from the conversation $V$.}

1. BR:ampure niki sanak, mulaian bae niki silak, gakn ruen jemaah niki.

(excusme son, just start the ceremony, just this the people come.)

2. UN: nggih bpk, cobak te antehn semendak.

(yes, sir. Let's wait amoment.)

\section{Arak niki jemaah sak masih lek jalan kemungkinan.}

(there are pople on the way maybe)

On the line 1 BR address UN with word "ampure" base alus form to ask someone, in this case, the way BR asked UN to start the ceremony. It is a polite form in base alus to begin a conversation which is base jamak just tract to the point. In return UN address BR with word "nggih" the polite form to show agreement and honors, before he starts to begin the ceremony. Meanwwhile AA address BR and UN with word "mangkin" the polite form of "ndot" to delay the ceremony begin earlier. Generally, all the sentences used in line 1-6 indicated to base alus. As mention before, three speakers of the conversation are non menak but they maintain their communication with base alus. Beside that, BR is older than UN but BR used base alus to UN in showing respect and honors because UN is "ustadsz" a religious figure in the community.

Once more, the writer found out that the religiousity level of people in the community at Dusun Tutuk influenced on the language style used in the daily communication of the community. Furthermore, the age factors do not influence in the choise of the language used. As the conversation above, BR used base alus to $\mathrm{UN}$ although $\mathrm{BR}$ is older than $\mathrm{UN}$ because $\mathrm{UN}$ is a religious figure in the community. It is used to show respect and honers.

Social position in the community (Kadus)

This following conversation will show how the social position influenced on the language style used in the community. This conversation is between BY (Bunjindal Yahya male 31 years old non noble Kadus), and AA (Amaq Andi 35 years old male male non noble). The conversation occured when AA come to BY's house talking about politic in Indonesia especially in Lombok. The following sample of communication is taken from conversation IV in the data at line 1-8.

\section{Exract 1.5 from the conversation IV}

1. BY: napi jarin yak bau sik tyang aturan?

(What should I talk about?)

2. AA: marak niki tuan kadus, kan mangkin taun politik, berembe pandangan pelinggih?

( Like this tuan Kadus, now is politic year, what is your opninion?) 
3. BY: nah mengenai politik niki jak nenten arak kepentingan pada dasarnya lamun tiang pribadi.

( Nah,, about this politic, personally, I do not have any interest in general.)

4. AA: ngih. Laguk berembe lek te suare masyarakat lamun lek pemilihhan presiden 0102 niki jak

(Yes. But how about people opinion here about presidential election 01 and 02.)

Base on the conversation the writer found that in this group of people, the use of language style is influenced by social position in the community. In this case, MY used word "napi" to address AA the alus form of "ape" which means "what" to ask AA even though AA and MY is not belonging to noble. In the covesation above, the language style used is an important thing for them. They do care about their language used in maintaining the conversation. It is shown by the language used although they both are non noble but they use base alus because they realise the position in the society as Kadus and of cousre AA used base alus to show his respect and honer to Kadus. It means that non noble people may use base alus if they communicate with non noble but has high position in the community like Kadus for instance, so the non noble who does not have power in the society (just ordinary people) used base alus.

\subsection{The Ralation between the Upward Mobility in Social Classes and Language Style Used}

After analyzing two previous aspects; language style used at Dusun Tutuk community and the factors that influence the upward mobility in social classes on the language style used at the community the writer found out that there is a relation between the language style used and the upward mobility in social classes on the language style used at Dusun Tutuk community. It may indicate the identity of people at the community. The writer found out that appropriate language is used to appropriate person regardless whether they are noble or non noble.

People at Dusun Tutuk community used base alus not because of the status as noble or non noble but rely on the sosial position in the community and follow up by the educational level. Language style used shown the identity of the speakers. The higher social position of the people at the community the higher language style will be used. In return the other people will respect and show the honors by addressing base alus or refined language to them.

Based on the expalnation above, the writer concluded that the language style used (base alus and base jamak) in the everyday communication at Dusun Tutuk community is one way to show the identity of the speakers. It is proof by those factors that have been explained in the previous section. Language style used at Dusun community based on the background profile of the speakers.

\section{Conclusion}

Dusun Tutuk community socially divided in to two groups. The first group is noble menak) and the second group is non noble (non menak). Absolutely base alus or refined language used to address menak to menak, non menak to menak, and menak to non menak. In return non menak to non menak will be addressed by base jamak. The use of base alus or refined language was as a form of respect of the social classes at the community.

However, after conducted the research the writer found out that the use of base alus and base jamak changed. There are several factors influencing the differences of language used at Dusun tutuk community, such as; educational level, religious level and social classes in community. Base alus was used to address people who well educated and religius figures in the community although they are indicated to non menak. They are respected by menak and non menak because of their knowladge and regiosity. In the other hand, person who had no power in the society, low income and low education will use base jamak in their daily activity even they are indicating to noble. Both noble and non noble will address them by base jamak. In addition, language is a symbol of identity where style was used as one way of showing the identity of the speakers. In the sasak community, appropriate language should be used to appropriate persons, regardless of the status as nobels or non nobbles. 


\section{References}

Alford, C. F. (1979). 'Review of Jurgen Habermas' Communication and the Evolution of Society,New German Critique, Vol 18, No.1: 76-80.

Bloomfield, L. (1995). Language. Jakarta: Garamedia. Pustaka Utama.

Devito, J.A. (1991). Human communication. New York: Haroers Collins Publiser Inc.

Creswell, J. W. (2012). Educational Research. Boston: Pearson Education Inc.

Fishman.J.A. (1971). Sociolinguistics: a brief introduction. New York: Newbury House.

Hymes, D.H. (ed). (1964). Languagein Culture and Society: A reader in Linguistics and Antrophology. New York: Harper \& Row.

Hymes, D. (1974). Foundation of Sociolinguistics: An Ethnography Approach. Philadelpia: University of Pensylvania.

Homles, J. (1992). An Inroduction of Sociolinguisticts. England: Longman Publishing.

Holmes, J. (2001). An Introduction to Sociolinguistics.London and New York: Routledge.

Hornby, A. S, and Gatenby, E. V. (1963). The Advanced Learner's Dictionaryof Current English. Great Britain: Oxpord University Press.

Khondker, H. B. (2004). Class and State in Bangladesh: Political Economy and Authoritarian Democracy. Bangladesh Studies, Vol.1 No.6: 28.

Labov.W. (2010).Principles of linguistic change: Social factors. In the series, Language in Society 29. Malden, MA: Blackwell Publishers.

Labov. W. (2010). Principles of Linguistics Change: Cognitive and Cultural Factors. United States: Blackwell Publishing.

Oxford dictionary. (1995). Learners Pocket Dictionary.Oxford University Presss.

Mahyuni. (2006). Speech Styles and Cultural Consciousness In Sasak Community. Mataram: Cerdas Press.

Mahyuni. (2007).ValuingLanguageandCulture:AnExampleFromSasak.Makara,SosialHumaniora,Vol.11, No.2,December2007:79-86.

Martini. R. (2002). Language and Group Identity. Unpublished thesis. Mataram University.

Patel, F. (2011). Intercultural Communication;Building a Global community.. New Delhi:SAGE Publications India Pvt Ltd.

Piotr, S. (2009). From Interaction to Symbol. A systems view of the evolution of signs and communication. Amsterdam/Philadelphia: John Benjamins Publishing Company. 
Rahman, S. (2007). Reproduction of Urban Classes in Bangladeshin the Context of Globalization. Washington D.C. : American University.

Samovar, L. A. (2007). Communication Between Cultures. Boston: Nelson Education, Ltd.

Santi, M.F. (2004). The Use of Personal Pronoun "de" and "em" to show Politeness in Sasak Language. Unpublished thesis. Mataram University.

Savile-troike. M. (2003). An Inroduction: The Ethnogrphy of Communication, Third Edition. Oxpord, UK: Blackwell Publishing Ltd.

Stella, T. (1989). Language, Communication, and Culture: Current Directions. London: Sage Publication, Inc.

Sugiyono. (2008). Metode Penelitian Kuantitatif Kualitatif dan R\&D. Bandung: Alfabeta.

Sumarsono. (2007). Sosiolinguistik. Yogyakarta: Sabda dan Pustaka belajar.

Wolfson, N. (1989). Perspectives: Sociolinguistics and TESOL.New York: Newbury House Publishers.

\section{Copyrights}

Copyright for this article is retained by the author(s), with first publication rights granted to the journal. This is an open-access article distributed under the terms and conditions of the Creative Commons Attribution license (http://creativecommons.org/licenses/by/4.0/). 